\title{
Implementation of Lean Kaizen to Reduce Waiting Time for the Indonesian Health Social Security Agency Prescription Services in Hospital Pharmacy Installation
}

\author{
Vera Yuliati ${ }^{1}$ (D), Helen Andriani ${ }^{2 *}$ (D) \\ ${ }^{1}$ Master of Hospital Administration Study Program, Faculty of Public Health, Universitas Indonesia, Depok, Indonesia; \\ ${ }^{2}$ Department of Health Policy and Administration, Faculty of Public Health, Universitas Indonesia, Depok, Indonesia
}

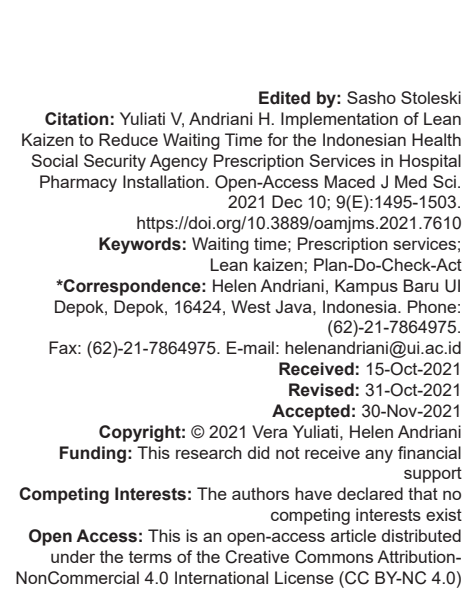

\section{Introduction}

Academics, professionals, and healthcare practitioners have been concerned about improving healthcare quality [1]. Hospital pharmacy is an integral part of the health service system in hospitals that are oriented toward patient care. As a result, its efficiency is inextricably related to patient satisfaction and, more importantly, the hospital's overall credibility [2]. All pharmaceutical activities are shown to provide direct services to patients for inpatients, outpatients, and all hospital units. The purpose of pharmaceutical service activities is closely related to identifying, preventing, and resolving drug-related problems [3]. The expansion of the paradigm change, from product-oriented (drugoriented) to patient-oriented, must be done to answer the demands of patients and society for improving the quality of pharmaceutical services [4].
One of the quality indicators of pharmaceutical services regulated in the Hospital Minimum Service Standards is the waiting time for non-concoction and concoction drugs. The waiting time for drug service is the time required from the time of the patient submitting the prescription to the patient receiving the drug. The annual report data for pharmacy division in 2018-2019 showed that there was about $40 \%$ of non-BPJS Health patient prescriptions which have not reached the standard requirement of waiting time, while for BPJS Health patient, there was more than $90 \%$ of the prescriptions which have not achieved the set standard of waiting time. Based on these data, there is an urgency to improve the minimum service standards for prescription services for BPJS Health patients, as it is still very far from achieving the minimum standard requirement.

Long queues at hospital pharmacy installation services for BPJS Health patients are common in various hospitals in Indonesia, especially in Java Island. The 
study site, Grha Permata Ibu (GPI) Hospital, is one of the private hospitals in Indonesia which is trying to improve the quality of services, with the main focus for being patient-oriented hospital, because the average number of outpatient visits reaches 19,000-20,000/month. GPI Hospital is also the second largest patient visits of Health Social Security Agency (BPJS Health), a public legal body in Indonesia to provide universal health care to its citizens, with an average of BPJS Health outpatient visit of 11,000-12,000 visits/month, or 400-600 visits/day. Consequently, it has an impact on the high number of prescription services. Besides, there is an urgency from the board of directors and management of GPI Hospital to make immediate improvements in terms of reducing waiting time in pharmacy installations in order to meet the quality indicators of pharmaceutical services. Previous research looks at the quality of healthcare services and related topics of patient dissatisfaction with the long waiting time [5], [6], [7]. The long waiting time causes patients with weak physical conditions to often complain of fatigue, boredom, discomfort, and stress. This creates a negative perception of the quality of hospital services so that patient satisfaction and trust decreases [8]. In short, reducing the waiting time will increase the patients' satisfaction as the main goal on quality indicators.

Waiting is a type of critical waste that must be eliminated to increase product value and increase customer value. Waste elimination using a lean approach can be used to improve the prescription service process at the Hospital Pharmacy Installation. One of the most widely applied lean kaizen methods is the Plan-Do-Check-Act (PDCA) cycle [9]. The PDCA cycle is characterized by a continuous improvement approach as a logical program that enables increased of activity [10]. Several previous lean method studies related to the analysis of waiting time in pharmacy services have been carried out. However, most of the outputs only proposing some improvement based on the findings of value added activities, nonvalue added activities, types of waste, and the root of causes [11], [12], [13], [14]. Therefore, there was a little real improvement to the service process at hospital. In contrast to other studies, researchers intervened the prescription service process by applying lean tools with the aim of achieving continuous improvement. This is a novel approach and has never been applied in a similar study to improving healthcare management quality and outpatient pharmacy performance. The study aims to implement lean kaizen through PDCA approach to reduce the waiting time of the current state and future state for BPJS Health prescription services at GPI Hospital Pharmacy Installation.

\section{Methods}

This research is operational research with qualitative and quantitative approaches with the application of lean kaizen. Operational research focuses on various problems in activity and problemsolving techniques [15]. It is not only limited to analyze the problems found. Instead, the improvements and problem-solving were made in a real way. This research was conducted in October-December 2020 at the Outpatient Pharmacy Installation of GPI Hospital. Data were collected by direct observation using the time and motion study technique by following the movement of the prescription directly from the entry prescription until the drug was handed over to the patient and in-depth interviews with the relevant informants.

The population in this study were all BPJS

Health outpatient prescriptions during 2020. The sample of the study was BPJS Health prescriptions at the Outpatient Pharmacy Installation on Monday-Friday from October to December 2020. The inclusion criteria were BPJS Health patient prescriptions and nonconcoctions at the Outpatient Pharmacy Installation in October-December 2020. The exclusion criteria were non-BPJS Health patient prescriptions, inpatient prescriptions, and Emergency Unit patient prescriptions. The number of samples was 30 prescriptions consisting of concoction and non-concoction prescriptions and seven informants for in-depth interviews. The minimum number of samples that must be taken by researchers is as many as 30 prescription samples [16]. The sample size for a viable study in the study is between 30 and 500 [17]. To select and determine the informants, the researchers used a purposive sampling method [18]. Samples were observed and followed directly from the beginning to the end of the process. Data were collected by direct observation using the time and motion study technique by following the movement of the prescription directly from the entry prescription until the drug was handed over to the patient and in-depth interviews with the relevant informants with due observance of the health protocol.

The data were analyzed and classified based on the type of waste, confirmed by data from in-depth interviews. The researcher implemented lean kaizen with four stages of the PDCA cycle:

\section{Plan}

In this stage, there is a priority problem improvement and determination of quality improvement. The present process situation was defined based on consistent data. The cause of the problem and the proposed solution was determined. The calculation of lead time (LT), total value-added time (VAT) and total non-VAT (NVAT) were obtained from the value stream map process in the present and future conditions. Data processing was carried out by Microsoft Excel, and qualitative data were collected from selected informants and narrated descriptively. Then, we looked for the root of the research problem using a 5 whys approach. 


\section{Do}

This stage is intended to implement a plan of action by selecting and documenting all information including unexpected events, lessons learned, and knowledge gained. In this study, the recommendations were submitted to the board of directors through several meetings, and then the implementation of improvements was carried out according to the recommendations.

\section{Check}

The results of the actions applied in the previous step were analyzed. The results before and after intervention were also compared to see if there was an improvement.

\section{Act}

This stage is the last cycle of PDCA which consists of development methods aimed at standardizing improvements.

Ethics is carried out by asking the respondent for informed consent before conducting direct observation and in-depth interviews. Participation is voluntary for the entire series of studies. All the collected information and the data obtained were guaranteed confidentiality. After obtaining research permission from the hospital and a letter of ethical review approval from the IRB at Universitas Indonesia, this research was conducted with the ethical review number: 652/UN2.F10.D11/ PPM.00.02/2020.

\section{Results}

\section{Plan}

The present state VSM for non-concoction prescription service process, starting from the prescription screening (i.e., time the patient submits the prescription) until the patient receives the drug. The prescription screening took an average of $71.90 \mathrm{~min}$ (range 45.55-115.08 $\mathrm{min}$ ), with VAT of $1.68 \mathrm{~min}(2 \%)$ and NVAT of $70.22 \mathrm{~min}(98 \%)$. The next stage is drug preparation (i.e., the time from the prescription being screened to the completion of the drug preparation), which took an average of $44.20 \mathrm{~min}$ (range $28.06-51.43 \mathrm{~min}$ ), with VAT of $3.92 \mathrm{~min}(9 \%)$ and NVAT of $40.27 \mathrm{~min}(91 \%)$. The last process is drug dispensing (i.e., the average time needed from the completion of drug preparation until the patient receives the drug), which took an average of 19.23 min (range 6.37-32.86 $\mathrm{min}$ ), with VAT of $1.09 \mathrm{~min}(6 \%)$, and NVAT of $18.13 \mathrm{~min}(94 \%)$. The average LT of non-concoction prescription service was 135.31 min with a total VAT of $6.69 \min (5 \%)$ and a total NVAT of $128.62 \min (95 \%)$.

The process of the present state VSM for concoction prescriptions is not so different from nonconcoction prescriptions. The different is only on the preparation of drugs and the process of compounding drugs. VSM of concoction prescriptions took an average of $91.86 \mathrm{~min}$ (range 82.43-102.93 $\mathrm{min}$ ) with VAT of $1.95 \mathrm{~min}(2 \%)$ and NVAT of $89.91 \mathrm{~min}(98 \%)$ The drug preparation took an average of $75.45 \mathrm{~min}$ (range $71.4-81.31 \mathrm{~min}$ ), with VAT of $21.3 \mathrm{~min}(28 \%)$ and NVAT of $54.15 \mathrm{~min}(72 \%)$. The drug dispensing took an average of $17.86 \mathrm{~min}$ (range $8.75-26.86 \mathrm{~min}$ ) with VAT of $1.13 \mathrm{~min}(6 \%)$ and NVAT of $16.73 \mathrm{~min}(94 \%)$. The average LT of non-concoction prescription service was 185.17 min with a total VAT of $24.38 \mathrm{~min}(13.17 \%)$ and a total NVAT of $160.79 \min (86.83 \%)$.

Besides calculating time, non-value added activities (waste) were recorded and is followed by determining the type of waste. It was found that 12 nonvalue added activities obtained $53.3 \%$ of activities were waste of waiting with a total NVAT of $129 \mathrm{~min}, 40 \%$ of activities were waste of overprocessing with a total NVAT of $75 \mathrm{~min}$, and $6.7 \%$ of the activities were waste of motion with a total NVAT of 0.27 min (Table 1).

A spaghetti diagram in Figure 1 showed an illustration to identify the movement or motion. Most movements are in the drug preparation process, where the placement of generic drugs is in the hallway, while the placement of patent drugs is in the back area. Hence, when the officer looking for drugs in the generic medicine cabinet did not find it, the officer would go back to the patent medicine cabinet. Still, if it was not found in the patent medicine cabinet, the officer would return to the generic medicine cabinet hallway search again. Likewise, if the officer forgets the drug in question is included in the generic or patent category, it relies heavily on the memory of the officer. In addition, during the drug dispensing process, if there was a drug debt on the previous visit caused by a lack of medication in the pharmacy, when the drug was available, the officer had to turn around and go back to take the drug, then hand it over to the patient.

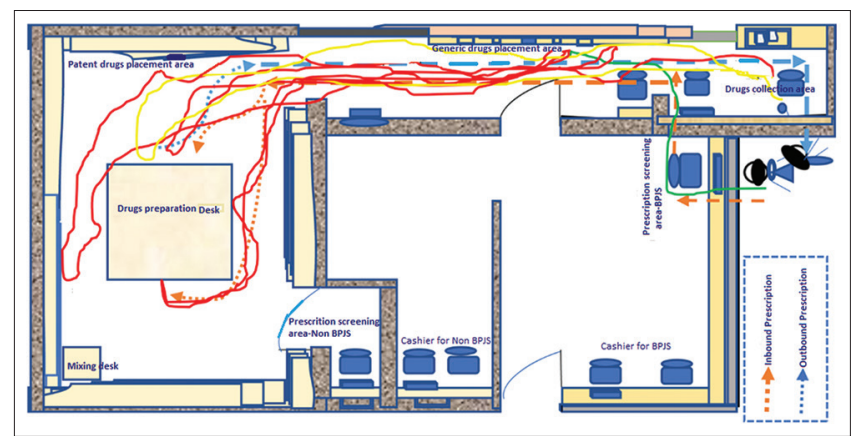

Figure 1: Spaghetti diagram

- The movement of prescription screening

- The movement of drug preparation

- The movement of drug dispensing 
The results of in-depth interviews with informants regarding confirm the root of the problem "why the waiting time at the pharmacy service is quite long" because of wrong behavior and mind set of officers (not lean), lack of human resources, lack of support from IT, complete stamp requirements on prescriptions from the finance department, and poor layout of outpatient pharmacies (Supplementary Table 1). The following are snippet of interviews to corroborate the results of the root causes:

Table 1: Types of waste from activity and NVAT

\begin{tabular}{lll}
\hline Types of waste & Activity $(\%)$ & NVAT (\%) \\
\hline Waiting & 53.3 & 82.2 \\
Overprocessing & 40 & 17.6 \\
Motion & 6.7 & 0.2 \\
\hline
\end{tabular}

The problem is because of the accumulation of prescriptions, doctors practice at the same time, so the prescriptions come piling up immediately. (Informant 1).

Human resources are lacking, input job is done by only one person, there is even one person doing two job desks, so for example, etiquette also mixes, the availability of many drugs is empty, so it takes time to make more debt receipts, copy the current recipe manually, the layout is not good, back and forth, turning and far. (Informant 2).

There are hours where doctors practice at the same time, while human resources are lacking, there are lots of prescriptions so the input is long, now the new system prescriptions copies are manual, also the rooms are far apart, the medicine is not properly placed so you have to go back and forth, the room is cramped. (Informant 3).

The prescription is not immediately received by the officer, in my opinion that is also a problem, the drug prescription is stacked first and then turned over and then inputted. (Informant 4).

As for the problems themselves, firstly because of the lack of human resources, the layout is back and forth, here pharmaceutical assistant is still doing some work, so it's still mobile, the system isn't right, it likes errors, it's still in the manual, including manual prescription copies. (Informant 5).

The obstacles are because of the lack of human resources, the long journey back and forth, the doctor's schedule at the same hour, the system sometimes has errors, sometimes it is slow, sometimes it can't, sometimes the doctor's writing is not clear. (Informant 6).

The constraints of the lack of human resources, the computer facilities and infrastructure have not been fulfilled, the layout has been back and forth, the front has not met the back, it hasn't been pasted the wrong way. (Informant 7).

\section{Do}

After finding the root of the problem, the researcher proceed with an action plan to reduce waiting time by eliminating non-value added activities using the lean kaizen method. The researcher first discussed with the head and staff of the pharmacy installation regarding the type of waste found at the plan stage, the root of the problem, and the suggestion plan for improvement. It was agreed that two scenarios were applied for improvement:

Scenario-1: There was no change in the flow of prescription process, but changing the habit of the staff by carrying out each process immediately without stacking the prescription.

Scenario-2: The location of prescription screening process was divided into: pharmacy 1 (screening of private-insurance patient prescriptions) and pharmacy 2 (screening BPJS Health patients) according to the layout redesign plan.

The prescription stamps were also eliminated after obtaining approval from finance. Finally, the researcher simulated the layout changes.

\section{Check}

At this stage, the results before and after intervention were also compared to see if there was an improvement.

Table 2 shows that there was a decrease in the total time of non-value added activities both in non-concoction and concoction prescriptions. At the

Table 2: Comparison between present state and future state value stream map after waste elimination

\begin{tabular}{|c|c|c|c|c|c|c|}
\hline & \multicolumn{6}{|l|}{ Types of Prescription } \\
\hline & \multicolumn{3}{|c|}{ Non-concoction prescription } & \multicolumn{3}{|c|}{ Concoction prescription } \\
\hline & Current state (min) & Future state-1 (min) & Future state-2 (min) & Current state (min) & Future state-1 (min) & Future state-2 (min) \\
\hline \multicolumn{7}{|c|}{ Prescription screening } \\
\hline VAT & 1.68 & 0.92 & 0.89 & 1.95 & 1.02 & 0.99 \\
\hline NVAT & 70.22 & 1.88 & 1.61 & 89.91 & 1.63 & 1.27 \\
\hline $\mathrm{C} / \mathrm{T}$ & 71.89 & 2.81 & 2.46 & 91.86 & 2.64 & 2.26 \\
\hline \multicolumn{7}{|c|}{ Drug preparation } \\
\hline VAT & 3.92 & 1.36 & 1.84 & 21.3 & 23.99 & 23.27 \\
\hline NVAT & 40.27 & 1.72 & 0.72 & 54.15 & 1.79 & 0.69 \\
\hline $\mathrm{C} / \mathrm{T}$ & 44.19 & 3.08 & 2.53 & 75.45 & 25.79 & 23.96 \\
\hline \multicolumn{7}{|c|}{ Drug dispensing } \\
\hline VAT & 1.09 & 1.18 & 1.04 & 1.13 & 1.05 & 1.39 \\
\hline NVAT & 18.13 & 2.04 & 1.45 & 16.73 & 1.6 & 1.54 \\
\hline $\mathrm{C} / \mathrm{T}$ & 19.23 & 3.22 & 2.49 & 17.86 & 2.65 & 2.93 \\
\hline \multicolumn{7}{|l|}{ Total } \\
\hline Total V & 6.69 & 3.46 & 3.73 & 24.38 & 26.07 & 25.66 \\
\hline Total NVA & 128.62 & 5.65 & 3.75 & 160.79 & 5.02 & 3.49 \\
\hline Lead time & 135.31 & 9.11 & 7.49 & 185.17 & 31.09 & 29.15 \\
\hline
\end{tabular}


beginning of the current state, it was found that the average LT or time needed to complete the entire process for every one prescription (prescription screening-drug preparation-drug dispensing) is $135.31 \mathrm{~min}$. After waste elimination is done, the future state condition scenario-1 LT drops to $9.11 \mathrm{~min}$ and scenario-2 LT drops to 7.49. The decrease occurred mainly in the NVAT, that is, the condition in the current state, the total NVAT was $128.62 \mathrm{~min}$. It decreased to $5.65 \mathrm{~min}$ in scenario-1 to $3.75 \mathrm{~min}$ in scenario-2.

The same thing was also found in the concoction prescription, which also saw a decrease in the total activity time and the total NVAT where at the beginning of the current state condition, it was found that the average LT or time needed to complete the entire process for every one prescription (prescription screening-drug preparation-drug dispensing) is $185.17 \mathrm{~min}$. After waste elimination is done, the future state condition scenario-1 LT drops to $31.09 \mathrm{~min}$ and Scenario-2 LT drops to 29.15. The decline occurred mainly in the NVAT, i.e. the condition in the current state, the total NVAT was $160.79 \mathrm{~min}$, then decreased to $5.02 \mathrm{~min}$ in Scenario-1 and became 3.49 min in Scenaio-2.

The research results found 12 non-value added activities in samples of non-concoction and concoction prescriptions. Of the 12 non-value added activities, $53.3 \%$ of wastes were waiting, $40 \%$ were overprocessing, and $6.7 \%$ were motion. Meanwhile, if calculated from the non-value added time, $82.2 \%$ of wastes were waiting, $17.6 \%$ were overprocessing, and $0.2 \%$ were motion.

\section{Act}

With the two scenarios above the goal is achieved, so that the mixed two processes need to be maintained. The location of prescription screening process can be divided into two places: pharmacy 1 (for screening private patient prescriptions) and pharmacy 2 (for screening prescriptions for BPJS Health patients), intense supervision must be carried out if necessary; one special supervisor from external pharmacy is given for the $1^{\text {st }}$ floor area including pharmacy. Layout changes still have to be processed so that there is no more waste of motion and IT support and even e-prescribing should be designed by the hospital.

\section{Discussion}

Hospitals all around the world have tried to use the lean management approach to improve the efficiency and effectiveness of their operations. Since the launch of the Indonesian National Health Insurance system on January 1, 2014, the implementation of lean management has increased in Indonesia. According to the Indonesian Minister of Health Regulation number: 129/Menkes/SK/II/2008 concerning Minimum Service Standards in Outpatient Installation states that the standard waiting time for drug service is $\leq 60 \mathrm{~min}$ for concoctions and $\leq 30 \mathrm{~min}$ for non-concoctions [19]. Minister of Health Regulation Number 11 of 2016 concerning the Implementation of Executive Outpatient Services in Hospitals also states that Hospitals providing Outpatient Services must maintain service quality through monitoring, evaluation, and improvement, which prioritizes: waiting time for outpatient services, patient satisfaction level, and the number of visits per month. Prolonged waiting time in the outpatient service has an impact on the long queues, thus causing inefficient services.

Based on the study results, the lack of optimal pharmacy services for BPJS Health users is caused by waiting $(53.3 \%)$, overprocessing $(40 \%)$, and motion $(6.7 \%)$. Waiting is common and ranks first among other types of process wastes. Processes are ineffective and time is wasted when one process waits to begin while another finishes. According to the previous research, as much as $99 \%$ of the product/service time is spent waiting [20]. Waste of overprocessing ranks second in this study. Overprocessing waste is adding unnecessary work and is caused by workers who have unclear standards and specifications. Many operators/ workers try to do the best work possible and do not always realize what is right. It adds value to their product or service. Overprocessing impacts on costs incurred; worker time is wasted, materials make equipment more easily damaged [20].

The two wastes are highly correlated with the staff's way of thinking that is not lean, that is, by stacking all processes with thoughts in a stacking way, make it easier for officers, so they don't have to go back and forth. Still, on the contrary, it makes the flow of each process not smooth, the finished prescription has to wait until other prescriptions are completed, apart from which some consumers or patients are at a disadvantage because they have to spend a lot of time waiting so long to get the medicine. Besides, a waste of motion of $6.7 \%$ of the total waste was also found. Waste of motion, that is, movement that is unnecessary and is a resource that is wasted when workers have to bend over, walk to reach distances in doing their work so that workplace ergonomic assessments must be carried out to design a more efficient environment [20]. Even though the waste of motion seems low (only $6.7 \%$ of the total waste), this causes the unsmooth flow of the process. It makes officers tired in carrying out each process so that officers deliberately pile up all processes to avoid back and forth activities.

In line with the perception of BPJS Health users, it is stated from the five why's method that waiting time in pharmaceutical services is caused by the behavior and thinking of officers who are not lean. The poor layout, lacking of human resources, and unsupported 
IT are the additional problems. Employee behavior is an important but often overlooked a part of starting a lean transformation. Much of the latest literature on lean business systems and methods is process-oriented, focusing on the implementation of technologies and techniques. There is still relatively little research on lean's human dimension [21], particularly employee motivation to think lean. Human resources (skills, beliefs, attitudes, and experiences of employees), according to Boyer and Smith, provide substantial economic benefit to the company [22]. The person-environment fit model, which has been influential in explaining workrelated outcomes such as job performance and job satisfaction [23], notes that positive outcomes occur when employees' aspirations, beliefs, and skills are aligned with their work environment. According to these models, when implementing lean reform, the company should understand workers and be mindful of the factors that influence employee willingness to think and behave leanly.

Employee engagement and dedication are critical to effective and long-term lean transformation [24]. Employee behavior is an important but largely neglected aspect of lean implementation by drawing on the organizational behavior and job psychology literature. Employees are encouraged to follow the lean system, which focuses on employee attitudes and responsibilities to make improvement [25]. Employees in management must be empowered to participate in waste elimination and constructive aspects of development by quality improvement activities (problem solving, target setting, decision-making).

The first step in lean thinking is understanding what value and activities to undertake and what resources needed to create that value. Once this is understood, then other activities that do not create that value are waste. Because, in essence, there are no workers who want what they do as waste. To develop a breakthrough with lean thinking, the first step is to learn to see waste. If an activity does not directly add value, it is called waste [26]. It is important that employee morale is critical to effective implementation. Employees must be inspired enough to interact proactively in their work environment and continually search for ways to change so that mistakes are eliminated and waste is avoided to ensure the smooth running of the production line. Workers who are motivated and adaptable are key ingredients in a lean production setting, and they have been described as one of the main drivers behind lean implementation success [27].

It is self-evident that employee morale is critical to effective implementation. Employees must be inspired enough to interact proactively in their work environment and continually search for ways to change so that mistakes are eliminated and waste is avoided in order for the production line to run smoothly. Workers who are motivated and adaptable are key ingredients in a lean production setting, and they have been described as one of the main drivers behind Wiremold's lean implementation success [27].

The lean kaizen approach with PDCA is very appropriate to improve the problems obtained from the results of this study, kaizen, which means a continuous improvement that involves everyone, both top management, managers, and employees [28]. A previous research that used lean tools to reduce waiting times showed that a lean strategy results in a reduction in the time required to complete activities and the elimination of waste [29]. A recent study about the efficiency of waiting time in outpatient pharmacy at a large public regional hospital also showed that lean manufacturing principles might be employed as an efficiency indicator for healthcare services quality. The findings will assist pharmacy managers in determining the causes of inefficiencies between departments and making necessary corrections to resolve the issues [14]. The essence of kaizen's strategy is to recognize that management must strive to satisfy customers and meet customer needs. As a permanent approach, kaizen is described as a complete PDCA loop and demands that group members not only identify problems but also identify causes, analyze them, implement and test new actions, and create a new standard procedure [30].

It is proven that after the PDCA approach is carried out, the future state conditions show a significant improvement. There is a decrease in the percentage of total NVAT or waste during the BPJS Health outpatient prescription service process both in the concoction and non-concoction prescriptions in Scenario-1 and Scenario-2. The lean theory, the focus of lean intervention is eliminating waste (non-value added activities), where in this research it is eliminating waiting, stacking, leaving prescriptions not being processed, delaying prescription processing, so that only activities that provide added value are left [31]. However, this reduction has not been maximized because there is still one waste that has not been removed, that is, the waste of motion. The previous research showed that the root cause of waste of motion is the manual system (hospital information system yet does not exist), and the separate spaces between rooms. Adding visual management and rearranging the room's layout are two suggestions for improvements to eliminate waste of motion optimally [32]. The PDCA approach is a continuous cycle, so that supervision must be carried out continuously [33]. The $4^{\text {th }}$ stage, that is, ACT has been carried out and implemented, and it is followed by stage-1 PLAN to continue to achieve improvements and so on until a good and smooth pattern is found. Nevertheless, the study highlights several limitations: The data collection process after intervention was supervised by the researchers, Deputy Director of Medical Services, and Head of Pharmacy Installation, while the daily process was not supervised. There is a concern that the officers will return to their previous behavior habits. The waste of motion has not been 
intervened, because for redesigning layout, it needs hospital board approval, budget, and time. Furthermore, the implementation of PDCA was only in a preliminary process, and has not yet been standardized.

\section{Conclusion}

The lean kaizen through PDCA approach, applied to BPJS Health prescription services at pharmacy installations, significantly reduces patient waiting time, so that standard indicators of the quality of waiting time for outpatient prescription services can be achieved. However, these results have not been maximized because there is still waste of motion that makes human resources/officers produce wastes of waiting and overprocessing. Therefore, the main plan of action is to impose a lean, customer-oriented mindset on officers. In addition, it is necessary to prioritize long-term improvements for outpatient prescription services, such as changes in service layout, continuous monitoring, and IT-based pharmacy through e-prescribing.

\section{Author Contributions}

Conceptualization: VY and HA Formal analysis: VY Methodology: VY and HA Supervision: HA Writingoriginal draft preparation: VY and HA Writing-review and editing: $V Y$ and $H A$. All authors contributed to the drafting, review and approval of this manuscript.

\section{Acknowledgments}

The researcher thanks the GPI Hospital and Faculty of Public Health, Universitas Indonesia, Depok, Indonesia.

\section{References}

1. World Health Organization, Organisation for Economic Co-Operation and Development and International Bank for Reconstruction and Development. Delivering Quality Health Services: A Global Imperative for Universal Health Coverage. Geneva: World Health Organization; 2018.

2. Zuber $M$, Alkhamis $A A$, Juned $M$, editors. Global Trends in University Hospitals. J Community Med Public Health. 2019;1(3):111-39.

3. Allemann SS, van Mil JW, Botermann L, Berger K, Griese N,
Hersberger KE. Pharmaceutical care: The PCNE definition 2013. Int J Clin Pharm. 2014;36(3):544-55. https://doi.org/10.1007/ s11096-014-9933-x

\section{PMid:24748506}

4. Direktorat Jenderal Bina Kefarmasian dan Alat Kesehatan Departemen Kesehatan RI. Standar Pelayanan Farmasi di Rumah Sakit. Jakarta, Indonesia: Direktorat Jenderal Bina Kefarmasian dan Alat Kesehatan Departemen Kesehatan Rl; 2006.

5. Bleustein C, Rothschild DB, Valen A, Valatis E, Schweitzer L, Jones R. Wait times, patient satisfaction scores, and the perception of care. Am J Manag Care. 2014;20(5):393-400. PMid:25181568

6. Alam S, Osama M, Iqbal F, Sawar I. Reducing pharmacy patien waiting time. Int J Health Care Qual Assur. 2018;31(7):834-44. https://doi.org/10.1108/IJHCQA-08-2017-0144

PMid:30354876

7. Al-Harajin RS, Al-Subaie SA, Elzubair AG. The association between waiting time and patient satisfaction in outpatient clinics: Findings from a tertiary care hospital in Saudi Arabia. J family Community Med. 2019;26(1):17-22. https://doi. org/10.4103/jfcm.jfcm_14_18

PMid:30697100

8. Maharani AE. Gambaran Waktu Tunggu Pelayanan Resep Pasien BPJS Pada Peak Hours di Depo Farmasi Rawat Jalan RSUP Fatmawati Tahun 2015. Depok: Universitas Indonesia; 2015.

9. Gaspersz V, Fontana A. Lean Six Sigma for Manufacturing and Service Industries: Waste Elimination and Continuous Cost Reduction Bogor. Bogor: Vinchristo Publication; 2011.

10. Oliveira J, Sá JC, Fernandes A. Continuous improvement through "Lean Tools": An application in a mechanical company. Procedia Manuf. 2017;13:1082-9.

11. Fauzia U, Setiawati EP, Surahman ES. Analysis of waiting time for filing prescriptions in hospital pharmacy. Pharmacol Clin Pharm Res. 2017;2(3):75.

12. Loh BC, Wah KF. Impact of value added services on patient waiting time at the ambulatory pharmacy Queen Elizabeth Hospital. Pharm Pract (Granada). 2017;15(1):846. https://doi. org/10.18549/PharmPract.2017.01.846 PMid:28503218

13. Kusumowardhani $D$, llyas $Y$, editors. Waiting Time of Pharmacy Service as an Indicator of Patient Satisfaction: A Systematic Review. The $6^{\text {th }}$ International Conference on Public Health; 2019.

14. Alodan A, Alalshaikh G, Alqasabi H, Alomran S, Abdelhadi A, Alkhayyal B. studying the efficiency of waiting time in outpatient pharmacy. MethodsX. 2020;7:100913. https://doi.org/10.1016/j. mex.2020.100913 PMid:32461924

15. Rais A, Viana A. Operations research in healthcare: A survey. Int Trans Oper Res. 2011;18(1):1-31.

16. Cohen L, Manion L, Morrison K. Research Methods in Education $3^{\text {rd }}$ ed. Newyork: Routledge 270 Madison Avenue; 2007.

17. Sugiyono D. Metode Penelitian Bisnis. Bandung: Alfabeta; 2012.

18. Patton M. Qualitative Research and Evaluation Methods: 2002. Available from: http://www.Ist-iiepiiep-unescoorg/cgi$\mathrm{bin} / \mathrm{wwwi32exe} /[\mathrm{in}=$ epidoc $1 \mathrm{in}] /$ ?t2000=018602/(100). [Last accessed on $2020 \mathrm{Jul}$ 21].

19. Standar Pelayanan Minimal Rumah Sakit, Keputusan Menter Kesehatan Republik Indonesia Nomor: 129/Menkes/SK/II/2008; 2008.

20. Hicks BJ. Lean information management: Understanding and eliminating waste. Int J Inform Manage. 2007;27(4):233-49. 
21. Hines $\mathrm{P}$, Holweg M, Rich N. Learning to evolve. Int J Oper Prod Manage. 2004;24:994-1011.

22. Boyer GR, Smith RS. The development of the neoclassical tradition in labor economics. ILR Rev. 2001;54(2):199-223.

23. Tinsley HE. The congruence myth: An analysis of the efficacy of the person-environment fit model. J Vocat Behav. 2000;56(2):147-79.

24. Bramble T. In: Womack JP, Jones DT, Roos D. Book Reviews: The Machine that Changed the World. New York: Rawson Associates; 1990. p. 323.

25. Baldus $\mathrm{O}$, Heckmann C. Lean IP-management-savings costs for IP management based on a paradigm change in assessing inventions. Am J Ind Bus Manage. 2017;7:760-70.

26. Beale J. Employee motivation to adopt lean behaviours: Individual-level antecedents. Rev Adm FACES J. 2007;6:11-31.

27. Fiume OJ. Lean at wiremold: Beyond manufacturing, putting people front and center. J Organ Excell. 2004;23(3):23-32.

28. Putra NN. Analisis Penerapan Budaya Kaizen Pada Perusahaan Joint Venture Asal Jepang di Indonesia (Studi pada PT. X).
Indonesia: Fakultas IImu Administrasi Universitas Brawijaya; 2018.

29. Lot LT, Sarantopoulos A, Min LL, Perales SR, Boin I, Ataide EC. Using lean tools to reduce patient waiting time. Leadersh Health Serv (Bradf Engl). 2018;31(3):343-51. https://doi.org/10.1108/ LHS-03-2018-0016

PMid:30016918

30. Imai K, King G, Stuart EA. Misunderstandings between experimentalists and observationalists about causal inference. J R Stat Soc Ser A Stat Soc. 2008;171(2):481-502.

31. Spagnol G, Li L, Min L, Newbold D. Lean principles in healthcare: An overview of challenges and improvements. Vol. 6. In: IFAC Proceedings Volumes (IFAC-Papers Online); 2013.

32. Dinda Sri R, Titik S, Opstaria S. Lean hospital approach toidentify critical waste of drug services in the outpatientpharmacy installation at RSUD X Manna in 2020. Media Ilmu Kesehatan. 2021;9(3):231-6.

33. Realyvásquez A, Arredondo-Soto $\mathrm{K}$, Carrillo-Gutiérrez $\mathrm{T}$, Ravelo G. Applying the plan-do-check-act (PDCA) cycle to reduce the defects in the manufacturing industry. A case study. Appl Sci. 2018;8:1-17. 


\section{Supplementary Table}

\section{Supplementary Table 1: Root cause analysis uses the 5 why's method}

\begin{tabular}{|c|c|c|c|c|c|c|c|}
\hline 5 WHY's & Why 1 & Why 2 & Why 3 & Why 4 & Why 5 & $\begin{array}{l}\text { Root of the } \\
\text { problem }\end{array}$ & Action plan \\
\hline \multirow[t]{6}{*}{$\begin{array}{l}\text { Outpatient pharmacy } \\
\text { quality indicators } \\
\text { have not been } \\
\text { achieved (BPJS } \\
\text { prescription service } \\
\text { time standards } \\
\text { have not reached } \\
\text { the specified } \\
\text { minimum standards; } \\
\text { non-concoction } \\
\text { prescriptions } \leq 30 \mathrm{~min} \text {, } \\
\text { concoctions } \leq 60 \mathrm{~min}\end{array}$} & $\begin{array}{l}\text { Prescriptions go at } \\
\text { the same time, the } \\
\text { doctor's practice } \\
\text { hours coincide }\end{array}$ & $\begin{array}{l}\text { Officers work } \\
\text { on prescriptions } \\
\text { at once in large } \\
\text { quantities (stacked) }\end{array}$ & $\begin{array}{l}\text { Officers think that } \\
\text { stacking (working } \\
\text { on a large number } \\
\text { of prescriptions) } \\
\text { will save more } \\
\text { time }\end{array}$ & $\begin{array}{l}\text { The officer thinks } \\
\text { that if it is done } \\
\text { one by one, the } \\
\text { officer must go } \\
\text { back and forth } \\
\text { and become } \\
\text { ineffective and } \\
\text { inefficient. Officers } \\
\text { were reluctant } \\
\text { to go back and } \\
\text { forth because the } \\
\text { locations of each } \\
\text { station were far } \\
\text { apart }\end{array}$ & $\begin{array}{l}\text { The behavior and } \\
\text { mindset of officers is } \\
\text { wrong and the layout is } \\
\text { not good }\end{array}$ & $\begin{array}{l}\text { The behavior } \\
\text { and mindset of } \\
\text { officers is wrong } \\
\text { and the layout is } \\
\text { not good }\end{array}$ & $\begin{array}{l}\text { - Approaching officers } \\
\text { to change their waste } \\
\text { behavior and replace it } \\
\text { with lean thinking. Stacking } \\
\text { prescriptions and working in } \\
\text { large quantities is waste, the } \\
\text { officer must change it by not } \\
\text { piling up prescriptions, every } \\
\text { time a prescription is done, } \\
\text { works quickly and is oriented } \\
\text { toward customer satisfaction, } \\
\text { not self-oriented } \\
\text { - Change of layout } \\
\text { - Setting work shifts by adding } \\
\text { a middle shift during peak } \\
\text { hours }\end{array}$ \\
\hline & $\begin{array}{l}\text { Mobile TTK officer/ } \\
\text { double job }\end{array}$ & $\begin{array}{l}\text { The number of TTK } \\
\text { officers is limited }\end{array}$ & Lack of TTK power & $\begin{array}{l}\text { Human resources } \\
\text { are lacking } \\
\text { based on WISN } \\
\text { calculations }\end{array}$ & $\begin{array}{l}\text { Human resources are } \\
\text { lacking }\end{array}$ & $\begin{array}{l}\text { Human resources } \\
\text { are lacking }\end{array}$ & Adding HR \\
\hline & \multirow{3}{*}{$\begin{array}{l}\text { Part of the } \\
\text { process is done } \\
\text { manually (giving } \\
\text { the prescription } \\
\text { serial number, } \\
\text { stamping paid } \\
\text { off, copy of the } \\
\text { prescription) }\end{array}$} & $\begin{array}{l}\text { Computerized error, } \\
\text { slow IT response }\end{array}$ & $\begin{array}{l}\text { IT systems often } \\
\text { crash }\end{array}$ & $\begin{array}{l}\text { Internet/internal } \\
\text { and external } \\
\text { networks are not } \\
\text { yet stable }\end{array}$ & $\begin{array}{l}\text { IT has other priorities } \\
\text { that must also be } \\
\text { addressed immediately }\end{array}$ & $\begin{array}{l}\text { IT has not fully } \\
\text { supported } \\
\text { outpatient } \\
\text { prescription } \\
\text { services }\end{array}$ & $\begin{array}{l}\text { Encourage IT to provide a good } \\
\text { support system for outpatient } \\
\text { prescription services }\end{array}$ \\
\hline & & New SIMRS problems & $\begin{array}{l}\text { The copy of the } \\
\text { prescription is not } \\
\text { yet in the new } \\
\text { SIMRS }\end{array}$ & $\begin{array}{l}\text { SIMRS has just } \\
\text { undergone a } \\
\text { transition from old } \\
\text { SIMRS to new } \\
\text { SIMRS }\end{array}$ & $\begin{array}{l}\text { The new SIMRS does } \\
\text { not yet support }\end{array}$ & $\begin{array}{l}\text { IT has not fully } \\
\text { supported } \\
\text { outpatient } \\
\text { prescription } \\
\text { services }\end{array}$ & \\
\hline & & $\begin{array}{l}\text { The cashier must have } \\
\text { proof of a paid stamp }\end{array}$ & $\begin{array}{l}\text { To make it easier } \\
\text { at the checkout, } \\
\text { so that the cashier } \\
\text { does not withdraw } \\
\text { payments. }\end{array}$ & Financial terms & - & Financial terms & $\begin{array}{l}\text { Abolishing the keel stamp, } \\
\text { because it is clear the BPJS } \\
\text { prescription }\end{array}$ \\
\hline & $\begin{array}{l}\text { Officer too much } \\
\text { movement }\end{array}$ & $\begin{array}{l}\text { To prepare medicine } \\
\text { and relay for each } \\
\text { process }\end{array}$ & $\begin{array}{l}\text { Prescription } \\
\text { screening in front, } \\
\text { drug preparation } \\
\text { behind, placement } \\
\text { of generic and } \\
\text { patent drugs apart, } \\
\text { and drug delivery } \\
\text { area back to front. }\end{array}$ & $\begin{array}{l}\text { Drug placement } \\
\text { and the location } \\
\text { of each post are } \\
\text { far apart }\end{array}$ & $\begin{array}{l}\text { Lay out of the room is } \\
\text { not suitable and slows } \\
\text { down movement }\end{array}$ & Lay out is bad & Change in layout, redesign, $5 \mathrm{~S}$ \\
\hline
\end{tabular}

